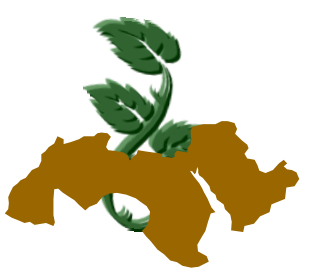

\title{
BIOLOGICAL CONTROL OF LASIODIPLODIA ROT OF MANGO FRUITS BY YEASTS
}

\author{
[33] \\ Shehata ${ }^{1}$, S.T. \\ 1- Department of Plant Pathology, Faculty of Agriculture, Ain Shams University, Shobra \\ El-Kheima, Cairo, Egypt
}

Keywords: Postharvest diseases; Mango; Biological control; Lasiodiplodia theobromae; Pichia guilliermondii; Candida multisgemmis; 1Methylcyclopropene

\section{ABSTRACT}

Ninety nine yeast isolates were isolated from surface of mango fruits and were tested in vivo in preliminary study for biocontrol potential of $\mathrm{La}$ siodiplodia rot of mango fruits. According to primary screening, nine isolates were selected to continue the secondary screening using different concentrations of the washed yeast cells in water suspension to study their biocontrol efficacy at $16 \pm 1^{\circ} \mathrm{C}$. It was found that using washed cells of yeast isolate $\mathrm{Mg} 147$ (Candida multisgemmis) at $1 \times 10^{9}, 5 \times 10^{8}$ and $2 \times 10^{8} \mathrm{CFU} / \mathrm{ml}$ produced complete protection for 14 days to wounds of mango fruit inoculated with spore suspension of the fungus Lasiodiplodia theobromae $1 \times 10^{5}$ conidia $/ \mathrm{ml}$. Meantime, no lesion developed on the mango fruit treated with the isolates $\mathrm{Mg} 39$ (Pichia guilliermondii strain A) at the highest tested colony forming unit (CFU) levels, i.e. $1 \times 10^{9}$ and $5 \times 10^{8} \mathrm{CFU} / \mathrm{ml}$. Supernatant of the yeast cultures, tested in secondary screening, did not prevent spore germination of $L$. theobromae or decay of wounded mango fruit but had inhibitory effect. However, 1Methylcyclopropene (1-MCP) treatment significantly reduced the infected area $\mathrm{mm}^{2}$ on mango fruit inoculated with $L$. theobromae $\left(1 \times 10^{5}\right.$ conidia $\left./ \mathrm{ml}\right)$ during the 14 days of storage at $16 \pm 1^{\circ} \mathrm{C}$ and improved efficacy of isolates Mg147 and Mg39. When applied as combined treatments between 1MCP and biocontrol agents, no lesion developed on the fruit treated with the isolate $\mathrm{Mg} 147$ at $1 \mathrm{x}$
$10^{8} \mathrm{CFU} / \mathrm{ml}$ or higher. Meanwhile, no lesion developed on the fruit treated with the isolate $\mathrm{Mg} 39$ at $2 \times 10^{8} \mathrm{CFU} / \mathrm{ml}$ or higher while, the percentages of rot reduction were ranged between $94.1 \%-81.3 \%$ for concentrations $1 \times 10^{8}$ and $6.6 \times 10^{7} \mathrm{CFU} / \mathrm{ml}$ respectively.

\section{INTRODUCTION}

In Egypt, cultivated area and total production of mango (Mangifera indica L.) have increased steadily in the last twenty five years. The total cultivation area increased from 37,000 feddan in 1987 to 240,804 feddan in 2012. Production increased from 110,000 tons in 1987 to 786,528 tons in 2012 (Anonymous, 2013). However, international and domestic trade of mango fruits have been limited because of its highly perishable nature and its susceptibility to low temperature injury, physical injury and post-harvest diseases (Mitra, 1997). In Bangladesh, the total losses due to post harvest pathological diseases from producer to consumer were about 27\% (Sarkar et al 2011). Stem-end rot of mango fruit presents one of the most serious postharvest problems (Prusky et al 2009) since the disease causes heavy losses in mangoes during storage (Mitra, 1997; Kobiler et al 2001). In Egypt, Botryodiplodia (Lasiodiplodia) theobromae responsible for stem end rot and represented $38.7 \%$ of total losses due to post harvest pathological diseases (Haggag, 2010). The disease has been reduced mainly through postharvest fungicides application and, to a lesser degree, through postharvest physical practices to reduce inoculum. Postharvest dipping, spraying or ultra-low-volume application of benomyl (where possible) effectively suppressed postharvest stem-end rot of mango 
(Plan et al 2002; Korsten, 2006). A treatment consisting of Hot water sprays over brushes $\left(55^{\circ} \mathrm{C}\right.$ for 15-20 s) and prochloraz followed by $(2,4-D)$ diluted in wax, reduced side and stem-end decay by $50-70 \%$, and improved fruit quality during prolonged storage (Kobiler et al 2001). However, postharvest use of fungicides has been increasingly curtailed by the development of pathogen resistance to many key fungicides (Spalding, 1982; XU et al 2004 and Hu et al 2013), lack of replacement fungicides, and public perception that pesticides are harmful to human health and the environment (Gullino \& Kuijpers, 1994; Ragsdale \& Sisler, 1994; Mari et al 2007 and Abano \& Sam-Amoah, 2012). Thus, alternative methods to control postharvest diseases are urgently needed (Conway, 1982; Wilson \& Pusey, 1985 and Wilson et al 1994; Falik et al 1995; Smilanick et al 1995; Smilanick et al 1999 and Tripathi et al 2013). Biological control is one of the alternatives, either alone or as a part of an integrated control strategy. Biological control has been extensively studied in the last twenty years and the use of yeasts and bacteria as antagonists has been reported to effectively control a number of postharvest diseases on many commodities (Patino-Vera et al 2005; Shehata et al 2006; Sharma et al 2009; Abano \& Sam-Amoah, 2012; Nunes, 2012; Spadaro et al 2013 and Nally et al 2013). However, biocontrol of Stem-end rot of mango fruit caused by $B$. theobromae received little attention. Preharvest applications of Bacillus licheniformis at 3-week intervals from flowering until harvest controlled moderate levels of anthracnose, and Stemend rot of mango fruit caused by Botryosphaeria spp., which suggests a potential treatment for commercial preharvest applications (Silimela and Korsten, 2006).

The ripening process of Mango is induced by ethylene (Mattoo \& Modi, 1969). Antagonists of ethylene have been well studied and in recent years, 1-Methylcyclopropene (1-MCP) has emerged as an excellent ethylene antagonist for commercial application (Blankenship \& Dole, 2003 and Watkins, 2006). 1-MCP has been proven to be very effective in delaying ripening, maintained fruit firmness and extending the shelf life of mangoes (Wang et al 2009 and Faasema et al 2014). The objectives of the present study were to isolate natural epiphytic yeasts from surface of mango fruits, investigate their biocontrol activity against Lasiodiplodia rot, either alone or as integrated with 1-MCP in storage, as well as identification of the most promising yeast isolates.

\section{MATERIALS AND METHODS}

\section{Plant material}

Mango fruits (Mangifera Indica) cultivars Baladi, Zebda and Ewais were obtained from commercial orchards in Fayoum governorate. Fruits were selected, from collecting boxes soon after harvest at mature green stage, uniform in shape, size and free from obvious mechanical damage or pathological symptoms.

\section{Pathogen}

The fungus Botryodiplodia theobromae Pat. Synonyms: Lasiodiplodia theobromae (Pat.) Griffon \& Maubl. was isolated from infected mango fruit during its marketing, confirmed its pathogenicity and identified according to Sutton, 1980 and Punithalingam, 1976 \& 1980. The cultures were maintained on potato dextrose agar (PDA) slants at $4 \pm 0.5^{\circ} \mathrm{C}$ until needed.

\section{Preparation of inoculum (spore Suspension)}

The fungal isolate of $L$. theobromae was grown on PDA, supplemented with $50 \mathrm{~g} / \mathrm{L}$ ripe mango fruit extract, at $25 \pm 1^{\circ} \mathrm{C}$ for 16 days. Conidia were harvested by flooding a sporulating culture with $10 \mathrm{ml}$ of sterile distilled water containing $0.03 \%$ Tween80 and dislodging conidia from conidiomata with a glass rod and vortexed for $1 \mathrm{~min}$. Conidial suspension was filtered through a double layer of sterile cheesecloth to remove mycelium parts and assure uniform mixing. Spore concentration was determined with a hemacytometer slide and adjusted to the desired concentration. Suspensions were used for inoculation within 1 hour.

\section{Isolation of biocontrol agents}

Potential yeasts were isolated from Mango fruits that were not exposed to chemical sprays for several weeks prior to picking. Isolates of yeasts present on the surface of the fruits were obtained by submerging individual fruit in a $600-1000 \mathrm{ml}$ beaker containing sterile phosphate buffer $(\mathrm{pH} 6.5)$ and $0.03 \%$ Tween- 80 . Beakers containing the fruits were covered by polyethylene sheet and rubber banded. Then Beakers were shaken on a rotary shaker at $120 \mathrm{rpm}$ for $30 \mathrm{~min}$. Serial 0.1 dilution's were plated on various media, mainly on acidified nutrient yeast dextrose agar (NYDA) me- 
dium (per litre: nutrient broth $8 \mathrm{~g}$, yeast extract $5 \mathrm{~g}$, dextrose $10 \mathrm{~g}$ and $20 \mathrm{~g}$ of agar), acidified malt yeast glucose peptone agar (MYGP) medium (per litre: malt extract $3 \mathrm{~g}$, yeast extract $3 \mathrm{~g}$, peptone $5 \mathrm{~g}$, glucose $10 \mathrm{~g}$, and $20 \mathrm{~g}$ of agar) and $\mathrm{pH}$ was adjusted with $(\mathrm{N}) \mathrm{HCl}$ to 4.5 for griping the growth of the other microorganisms. Plates were incubated at $21 \pm 0.5^{\circ} \mathrm{C}$ for $48 \mathrm{~h}$. After appearance of colonies, isolates were selected at random based on the visual characteristics (colour and shape), in addition to microscopic examination to distinguish the yeasts from the bacteria. Then, purification of isolated yeasts was made by triple re-streaking. If all colonies on the plate at the final streaking appeared uniform, they were assumed to be pure; if not, they were streaked additional three times. Pure selected isolates were transferred to malt extract agar (Malt extract $20 \mathrm{~g}$; Peptone $3 \mathrm{~g}$ and 18 $\mathrm{g}$ of agar) slants and stored under a phosphate buffer at $4 \pm 0.5{ }^{\circ} \mathrm{C}$ for further use (Janisiewicz, 1987 and 1991).

\section{Preparation of bioagents}

The cultures of the yeasts were activated on fresh slants and, after $24 \mathrm{hr}$ were transferred to 250 $\mathrm{ml}$ Erlenmeyer Flasks with sterile $50 \mathrm{ml}$ of nutrient yeast dextrose broth (NYDB) medium. The flasks were placed on a rotary shaker at $120 \mathrm{rpm}$ for 48 hr at $23 \pm 2^{\circ} \mathrm{C}$. A droplet, $25 \mu \mathrm{l}$, of liquid culture of the yeast was used in primary screening. For secondary screening, the liquid culture medium was then centrifuged at $10000 \mathrm{rpm}$ under cooling at $4^{\circ} \mathrm{C}$ for $10 \mathrm{~min}$, cells were re-suspended in $30 \mathrm{ml}$ sterile distilled water (SDW), and vortexed for 1 min, re-centrifuged and re-suspended in $10 \mathrm{ml}$ SDW. Serial desired concentrations in secondary screening were obtained by adjusting the suspension after cell yeast concentration was determined with a hemacytometer and confirmation were made by plate dilution method on the basis of colony forming unit (CFU/ml) (Janisiewicz, 1991).

\section{Fruit inoculation}

The fruits were washed with chlorinated water (250 ppm NaOCl), then air-dried. Two wounds were done per fruit between the calyx and stem end axis by the removal of a tissue block measuring $3 \times 3 \times 3 \mathrm{~mm}$. A droplet, $25 \mu \mathrm{l}$, of liquid culture of the yeast isolate in primary screening or $25 \mu$ of washed cells from each tested concentration was applied into each wound in secondary screening. Wounds were then inoculated with $25 \mu \mathrm{l}$ of the pathogen spore suspension $\left(1 \times 10^{4}\right.$ or $1 \times 10^{5}$ conid- $\mathrm{ia} / \mathrm{ml}$ ) of $L$. theobromae to each wound within 60 90 minutes. Wounds treated with sterile fresh NYDB, for primary screening, or SDW, for secondary screening and pathogen spore suspension were used as controls (Janisiewicz, 1991).

\section{Fruit incubation}

Each treated fruit was put on glass dish $(11 \mathrm{~cm}$ in diameter) and placed in cylindrical plastic box (16 $\mathrm{cm}$ in diameter by $12 \mathrm{~cm}$ in height) lined with wetted filter paper on the bottom, then the boxes were covered and incubated 6 days at $23 \pm 1^{\circ} \mathrm{C}$ for primary screening, 14 days at $16 \pm 1^{\circ} \mathrm{C}$ for secondary screening and for fruits treated by 1 Methylcyclopropene (1-MCP).

\section{Disease assessment}

Fruits were evaluated for rot development after incubation period. Mean of lesion diameter $(\mathrm{mm})$ was measured $=\mathbf{A}$. Infected area $\left(\mathrm{mm}^{2}\right)$ was calculated as $(\mathbf{A} / 2)^{2} \times 3.14$.

Percentage of infected area as compared with control (check) was calculated as infected area $\left(\mathrm{mm}^{2}\right)$ for treatment / infected area $\left(\mathrm{mm}^{2}\right)$ for control (check) x 100 .

\section{Testing the activity of culture filtrate}

Yeast cultures were centrifuged for separation of yeast cells, then the supernatant was filtered through a $0.22 \mu \mathrm{m}$ pore size nitrocellulose membrane and the following tests were carried out:

A) Spore germination tests: One $\mathrm{ml}$ of $L$. theobromae spore suspension $\left(1 \times 10^{5}\right.$ conidia $\left./ \mathrm{ml}\right)$ was mixed with $2 \mathrm{ml}$ of a cell free yeast culture filtrate and vortexed for $1 \mathrm{~min}$. For control, $2 \mathrm{ml}$ of sterile fresh NYDB medium was added instead of cell free yeast cultural filtrate. A $150 \mu$ droplet of yeast filtrate-conidia mixture was placed on a glass cavity slide and incubated at $24 \pm 1^{\circ} \mathrm{C}$ in moist chamber, made by placing wetted sterile filter paper in the Petri dish, for $21 \mathrm{~h}$. Then a drop of acid fuchsine in lactophenol was added to kill and stain conidia. The mixture was examined under light microscope $(\times 400)$ for recording germinated and nongerminated conidia in five randomly chosen microscopic fields per glass slide. Percentage of spore germination was calculated by dividing the number of germinating spores by total number of spores present per microscopic field multiplied by 100 . A spore was considered germinated when the germ tube length was 1.5 times the spore width. Four 
slides were used per treatment (PlascenciaJatomea et al 2003).

B) Mango fruit test: Zebda mango fruit were treated as described previously. Twenty-five $\mu \mathrm{l}$ of the supernatant was applied into each wound. This was followed by applying $25 \mu \mathrm{l}$ of the $L$. theobromae suspension $\left(1 \times 10^{5}\right.$ conidia/ml) within 60-90 minutes. Wounds treated with sterile fresh NYDB and pathogen spore suspension were used as control (check). The fruits were incubated as described previously for 6 days at $23 \pm 1^{\circ} \mathrm{C}$. Lesion diameter $(\mathrm{mm})$ was measured and infected area $\left(\mathrm{mm}^{2}\right)$ as well as percentage of infected area as compared with control (check) was calculated as mentioned before (Pusey \& Wilson, 1984).

\section{1- Methylcyclopropene (1-MCP) application}

1-MCP was applied on the day after harvest on mango fruit $\mathrm{cv}$. Ewais which were transported in refrigerated medium truck for overnight cooling at $13^{\circ} \mathrm{C}$. The fruit were washed using tap water and sterile water. No additional chlorine was added during washing to avoid any possible effect of chlorine on ripening. The fruits were allowed to dry out as a single layer on clean tables, sorted for uniformity in size, external colour and free from obvious mechanical damage or pathological symptoms. SmartFresh (0.14\% 1-MCP, Agrofresh, Inc., Rohm and Haas, PA, USA) was used to release 1$\mathrm{MCP}$, following the manufacturer's recommendations. 1-MCP was weighed in powder form $(625 \mathrm{~nL}$ $\mathrm{L}^{-1}, 1 \mathrm{~g}$ per $\mathrm{m}^{3}$ chamber) in a $100-\mathrm{mL}$ flask. Fifteen $\mathrm{mL}$ distilled warm water $\left(37^{\circ} \mathrm{C}\right)$ was added to release1-MCP and the flask was immediately closed. The flasks were taken to the treatment airtight chambers and its rubber cover was removed in the chambers that were immediately sealed, then the treatment started. After $24 \mathrm{~h}$ at $23^{\circ} \mathrm{C}$, the chambers were opened, ventilated, and the mango fruit in plastic containers were removed from the chambers. Then, the fruits were inoculated and incubated as mention previously in secondary screening.

\section{Identification procedure}

The two promising yeast isolates were identified at Unit of Microorganisms Identification and Biological Control, Agricultural Research Center, Giza using YT Biolog microplates of the Biolog system (Biolog Inc., Hayward, CA) according to the recommended procedure. The plates were inoculated with the yeast suspensions made from cultures grown in NYDB medium overnight, which were washed twice in sterile distilled water before application to the plates. The data from the YT plates were analyzed with the MLCLUST program (Biolog Inc.).

\section{Statistical analysis}

Four replicates per treatment each of 3 fruit were used in all experiments with exception of primary screening which used three replicates per treatment each of 2 fruit.

Data obtained were subjected to computer statistical software (ASSISTAT) originated by Silva \& Azevedo (2009). Data analyzed using analysis of variance (ANOVA), and mean values were compared using Duncan's multiple range test at a significance level of $P=0.05$.

\section{RESULTS}

\section{Primary screening}

The primary screening aimed to select isolates which were capable of reducing disease development by more than $95 \%$. The effectiveness of 99 yeast isolates, isolated from surface of mango fruits in reducing percentage of infected area as compared with control (untreated) of mango fruit was studied. Data in Table (1) and Photo (1) show that of 99 yeast isolates, only seven isolates completely protected wounded mango fruits from infection by $L$. theobromae $\left(1 \times 10^{4}\right.$ conidia/ml). These isolates were $\mathrm{Mg} \mathrm{10}, \mathrm{Mg} \mathrm{21}, \mathrm{Mg} \mathrm{39}, \mathrm{Mg} \mathrm{57,} \mathrm{Mg}$ 147, Mg 156, Mg 165 while the isolates Mg 111 and $\mathrm{Mg} 181$ inhibited the percentage of infected area as compared with control more than $99 \%$. Other twelve isolates, namely $\mathrm{Mg} \mathrm{28,} \mathrm{Mg} \mathrm{46,} \mathrm{Mg}$ 52, Mg 66, Mg 73, Mg 78, Mg 84, Mg 129, Mg 172, Mg 183, Mg 190, and Mg 192 suppressed the percentage of infected area as compared with control more than $95 \%$. Nine of these promising isolates were selected based on their efficacy for secondary screening.

\section{Secondary screening}

Secondary screening aimed to determine the effectiveness and usefulness of the potential antagonists selected in primary screening. The effective isolates which were selected from primary screening were used in the secondary screening. Serial dilutions i.e. $1 \times 10^{9}, 5 \times 10^{8}, 2 \times 10^{8}, 1 \times 10^{8}$, and $6.6 \times 10^{7}$ on the base of $\mathrm{CFU} / \mathrm{ml}$ of washed yeast cells water suspension were applied to study their biocontrol effect against $1 \times 10^{5}$ conidia $/ \mathrm{ml}$ of $L$. theobromae. Data in Table (2) \& Photo (2) indicate that all yeast isolates in this phase, especially 
at high doses, reduced percentage of rot as com- pare with control (check) when inoculated mango 
Table 1. Percentage of infected area as compared with control (PIACC) ${ }^{(1)}$ of wounded mango fruits $^{(2)}$ treated ${ }^{(3)}$ with different yeast isolates, and inoculated with conidia of Lasiodiplodia theobromae, then stored at $23 \pm 1^{\circ} \mathrm{C}$ for 6 days

\begin{tabular}{|c|c|c|c|c|c|c|c|c|c|}
\hline $\begin{array}{c}\text { Yeast } \\
\text { isolate }^{(4)}\end{array}$ & PIACC & $\begin{array}{c}\text { Yeast } \\
\text { isolate }\end{array}$ & PIACC & $\begin{array}{c}\text { Yeast } \\
\text { isolate }\end{array}$ & PIACC & $\begin{array}{c}\text { Yeast } \\
\text { isolate }\end{array}$ & PIACC & $\begin{array}{c}\text { Yeast } \\
\text { isolate }\end{array}$ & PIACC \\
\hline $\mathrm{Mg} 3$ & 25.9 & $\operatorname{Mg} 46$ & 1.3 & $\mathrm{Mg} 88$ & 16.9 & $\operatorname{Mg} 131$ & 50.2 & Mg 169 & 5.9 \\
\hline $\operatorname{Mg} 5$ & 40.9 & Mg 48 & 27.3 & Mg 91 & 5.5 & $\operatorname{Mg} 133$ & 54.3 & Mg 172 & 1.4 \\
\hline $\operatorname{Mg} 6$ & 15.5 & Mg 50 & 53.9 & $\operatorname{Mg} 93$ & 31.4 & $\operatorname{Mg} 136$ & 35.7 & $\operatorname{Mg} 173$ & 10.6 \\
\hline $\operatorname{Mg} 9$ & 24.2 & Mg 52 & 4.7 & Mg 95 & 31.7 & $\operatorname{Mg} 138$ & 27.0 & Mg 174 & 32.0 \\
\hline $\operatorname{Mg} 10$ & 0.0 & Mg 55 & 35.3 & $\operatorname{Mg} 97$ & 27.6 & $\mathrm{Mg} 140$ & 45.1 & Mg 176 & 10.6 \\
\hline $\operatorname{Mg} 11$ & 37.4 & Mg 57 & 0.0 & Mg 99 & 6.9 & $\operatorname{Mg} 142$ & 6.3 & Mg 177 & 6.8 \\
\hline $\operatorname{Mg} 14$ & 36.3 & $\mathrm{Mg} 60$ & 23. 6 & Mg 102 & 44.3 & $\mathrm{Mg} 145$ & 9.9 & $\operatorname{Mg} 178$ & 44.3 \\
\hline $\operatorname{Mg} 16$ & 26.4 & Mg 61 & 20.4 & Mg 104 & 7.8 & $\operatorname{Mg} 147$ & 0.0 & $\operatorname{Mg} 180$ & 12.6 \\
\hline $\operatorname{Mg} 19$ & 8.3 & Mg 64 & 26.4 & $\operatorname{Mg} 106$ & 16.5 & $\operatorname{Mg} 150$ & 51.4 & Mg 181 & 0.4 \\
\hline $\operatorname{Mg} 20$ & 41.7 & Mg 66 & 1.2 & Mg 109 & 36.7 & Mg 151 & 39.2 & $\operatorname{Mg} 183$ & 2.5 \\
\hline $\operatorname{Mg} 21$ & 0.0 & $\operatorname{Mg} 68$ & 54.3 & Mg 111 & 0.4 & Mg 154 & 24.2 & $\operatorname{Mg} 185$ & 5.5 \\
\hline $\operatorname{Mg} 23$ & 20.4 & Mg 69 & 22.2 & $\operatorname{Mg} 115$ & 36.7 & $\operatorname{Mg} 156$ & 0.0 & $\operatorname{Mg} 187$ & 22.5 \\
\hline $\operatorname{Mg} 25$ & 40.6 & Mg 70 & 18.9 & Mg 118 & 17.9 & Mg 158 & 17.2 & Mg 189 & 21.9 \\
\hline $\operatorname{Mg} 27$ & 34.9 & Mg 73 & 2.3 & $\operatorname{Mg} 119$ & 7.5 & $\operatorname{Mg} 159$ & 33.6 & Mg 190 & 2.0 \\
\hline $\operatorname{Mg} 28$ & 2.3 & Mg 75 & 35.7 & Mg 120 & 33.6 & Mg 160 & 58.2 & Mg 191 & 39.6 \\
\hline $\mathrm{Mg} 30$ & 22.5 & Mg 77 & 44.3 & $\operatorname{Mg} 121$ & 37.0 & Mg 163 & 14.0 & Mg 192 & 1.1 \\
\hline $\mathrm{Mg} 34$ & 42.4 & Mg 78 & 3.4 & Mg 123 & 28.5 & Mg 164 & 30.1 & Mg 194 & 30.4 \\
\hline $\operatorname{Mg} 37$ & 33.0 & Mg 82 & 9.9 & Mg 124 & 26.2 & Mg 165 & 0.0 & Mg 196 & 7.7 \\
\hline Mg 39 & 0.0 & Mg 84 & 1.2 & Mg 127 & 10.1 & Mg 167 & 21.7 & Mg 199 & 32.9 \\
\hline $\operatorname{Mg} 43$ & 26.4 & Mg 86 & 43.6 & $\operatorname{Mg} 129$ & 1.3 & $\operatorname{Mg} 168$ & 39.5 & Control(5) & 100.0 \\
\hline
\end{tabular}

(1) PIACC $=$ Infected area $\left(\mathrm{mm}^{2}\right)$ for treatment/ Infected area $\left(\mathrm{mm}^{2}\right)$ for control $\times 100$.

(2) Mango fruit cv. Balady treated at mature green stage.

(3) Mango fruit inoculated by $25 \mu \mathrm{l}$ of liquid culture from each tested isolate and $60-90$ minutes later challenged with $25 \mu \mathrm{l} 1 \times 10^{4}$ conidia/ml of $L$. theobromae.

(4) Yeast isolates sources were mango fruits that did not exposed to chemical sprays for several weeks prior to picking.

(5) Wounds treated with sterile fresh NYDB and pathogen spore suspension were used as control (check).
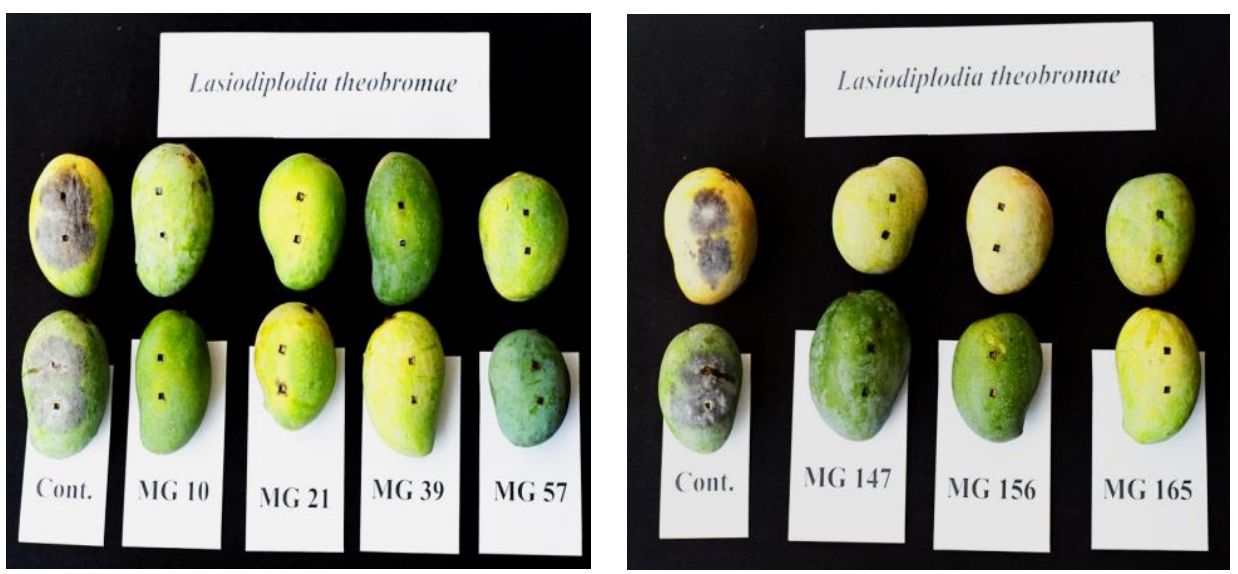

Photo 1. Development of Lasiodiplodia rot in wounded mango fruit treated with different yeast isolates and challenged with conidia of $L$. theobromae, then stored at $23 \pm 1^{\circ} \mathrm{C}$ for 6 days. 
Table 2. Infected area $\mathrm{mm}^{2}$ and Percentage of infected area as compared with control (PIACC) $^{(1)}$ of wounded mango fruit ${ }^{(2)}$, treated (3) with different concentrations of yeast cells of nine isolates, and inoculated with Lasiodiplodia theobromae, then stored at $16 \pm 1^{\circ} \mathrm{C}$ for 14

\begin{tabular}{|c|c|c|c|c|c|c|c|}
\hline \multicolumn{2}{|c|}{ Concentration (CFU/ml) } & $1 \times 10^{9}$ & $5 \times 10^{8}$ & $2 \times 10^{8}$ & $1 \times 10^{8}$ & $6.6 \times 10^{7}$ & Control $^{(4)}$ \\
\hline \multicolumn{8}{|c|}{ Isolates ${ }^{(5)}$} \\
\hline \multirow{2}{*}{ Mg 10} & Area $\mathrm{mm}^{2}$ & $880.9 \mathrm{~g}$ & $1153.5 \mathbf{f}$ & $1362.8 \mathrm{e}$ & $1852.8 \mathrm{c}$ & $1982.1 \mathrm{c}$ & 2663.5 a \\
\hline & PIACC & 33.1 & 43.3 & 51.2 & 69.6 & 74.4 & 100 \\
\hline \multirow{2}{*}{$\operatorname{Mg} 21$} & Area $\mathrm{mm}^{2}$ & $783.0 \mathrm{~g}$ & $1143.5 \mathrm{f}$ & $1548.6 \mathrm{~d}$ & $1814.9 \mathrm{c}$ & $1840.1 \mathrm{c}$ & 2663.5 a \\
\hline & PIACC & 29.4 & 42.9 & 58.1 & 68.1 & 69.1 & 100 \\
\hline \multirow{2}{*}{ Mg 39} & Area $\mathrm{mm}^{2}$ & $0.0 \mathrm{n}$ & $0.0 \mathrm{n}$ & $72.1 \mathrm{~m}$ & $263.8 \mathbf{j}$ & $679.3 \mathbf{h}$ & $2663.5 \mathbf{a}$ \\
\hline & PIACC & 0.0 & 0.0 & 2.7 & 9.9 & 25.5 & 100 \\
\hline \multirow{2}{*}{$\operatorname{Mg} 57$} & Area $\mathrm{mm}^{2}$ & $1060.2 \mathbf{f}$ & $1199.1 \mathbf{f}$ & $1429.0 \mathrm{~d}$ & 2115.8 b & 2317.4 b & $2663.5 \mathbf{a}$ \\
\hline & PIACC & 39.8 & 45.0 & 53.7 & 79.4 & 87.0 & 100 \\
\hline \multirow{2}{*}{ Mg 111} & Area $\mathrm{mm}^{2}$ & $641.4 \mathrm{~h}$ & $812.2 \mathbf{g}$ & $1468.3 \mathrm{~d}$ & $1871.9 \mathrm{c}$ & 2410.7 a & $2663.5 \mathbf{a}$ \\
\hline & PIACC & 24.1 & 30.5 & 55.1 & 70.3 & 90.5 & 100 \\
\hline \multirow{2}{*}{ Mg 147} & Area $\mathrm{mm}^{2}$ & $0.0 \mathrm{n}$ & $0.0 \mathrm{n}$ & $0.0 \mathrm{n}$ & $152.0 \mathrm{I}$ & $439.7 \mathbf{i}$ & 2663.5 a \\
\hline & PIACC & 0.0 & 0.0 & 0.0 & 5.7 & 16.5 & 100 \\
\hline \multirow{2}{*}{ Mg 156} & Area $\mathrm{mm}^{2}$ & $925.3 \mathbf{g}$ & $1643.1 \mathrm{~d}$ & $1904.1 \mathrm{c}$ & 2122.6 b & 2417.9 a & 2663.5 a \\
\hline & PIACC & 34.7 & 61.7 & 71.5 & 79.7 & 90.7 & 100 \\
\hline \multirow{2}{*}{ Mg 165} & Area $\mathrm{mm}^{2}$ & $859.2 \mathbf{~ g}$ & $952.5 \mathbf{~ g}$ & 1777.4 c & $2136.3 \mathbf{b}$ & 2572.9 a & 2663.5 a \\
\hline & PIACC & 32.3 & 35.8 & 66.7 & 80.2 & 96.6 & 100 \\
\hline \multirow{2}{*}{ Mg 181} & Area $\mathrm{mm}^{2}$ & 561.7 h & $970.8 \mathbf{g}$ & 1368.3 e & $1601.4 \mathrm{~d}$ & $1878.3 \mathrm{c}$ & 2663.5 a \\
\hline & PIACC & 21.1 & 36.4 & 51.4 & 60.1 & 70.5 & 100 \\
\hline
\end{tabular}

(1) PIACC = Infected area $\left(\mathrm{mm}^{2}\right)$ for treatment/ Infected area $\left(\mathrm{mm}^{2}\right)$ for control $\times 100$.

(2) Mango fruit cv. Zebda treated at mature green stage.

(3) Mango fruit inoculated by $25 \mu \mathrm{l}$ of different concentrations of washed cells of tested yeast isolates and $60-90$ minutes later challenged with $25 \mu \mathrm{l} 1 \times 10^{5}$ conidia $/ \mathrm{ml}$ of $L$. theobromae.

(4) Wounds treated with sterile distilled water and pathogen spore suspension were used as control (check).

(5) Yeast isolates sources were mango fruits that did not exposed to chemical sprays for several weeks prior to picking.

(6) Means followed by the same letter are not significantly different according to Duncan's multiple range test $(p=0.05)$.

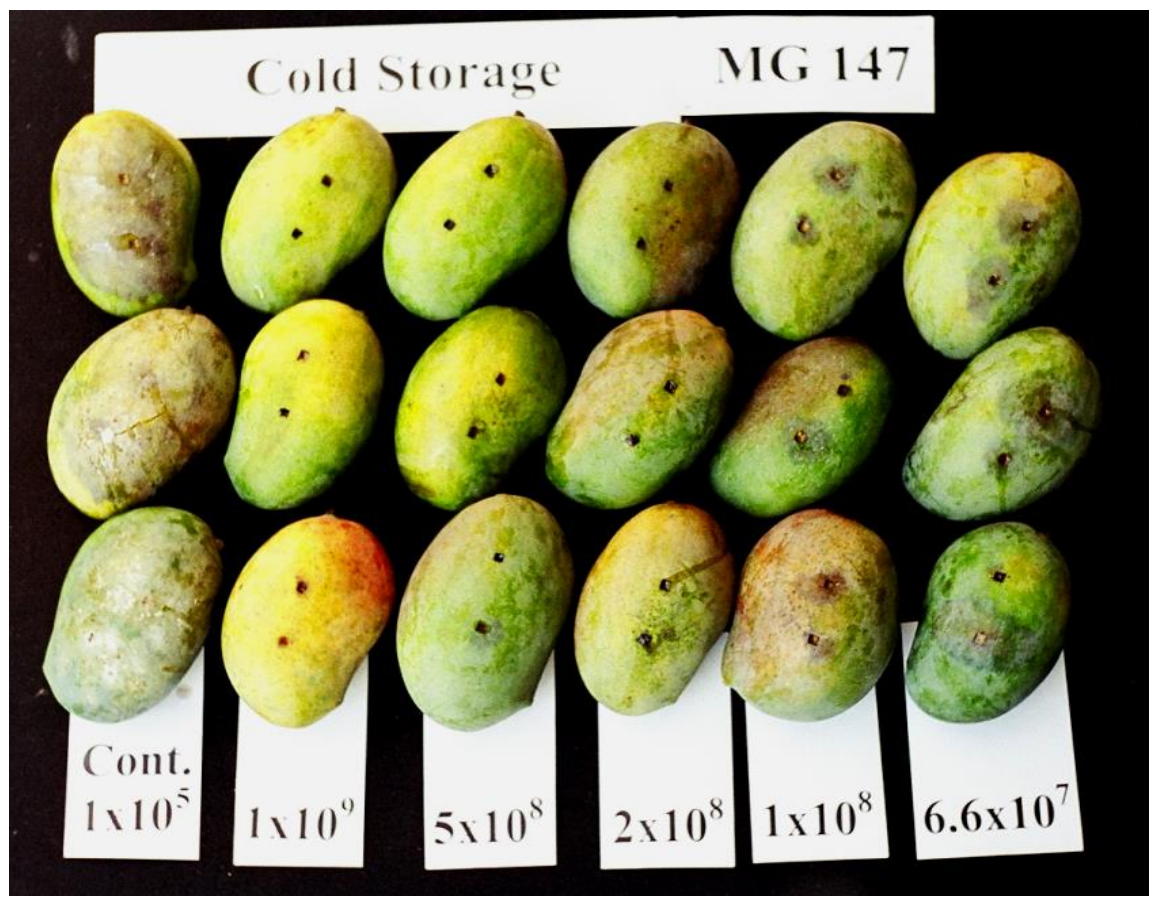

Photo 2. Development of Lasiodiplodia rot in wounded mango fruit treated with different concentrations of washed yeast cells of the best tested isolate and challenged with conidia of $L$. theobromae, then stored at $16 \pm 1^{\circ} \mathrm{C}$ for 14 days. 
fruits were stored for 14 days at $16 \pm 1^{\circ} \mathrm{C}$. No lesion developed on the fruit treated with the isolates $\mathrm{Mg}$ 39 and $\mathrm{Mg} 147$ at the highest tested concentration of the antagonist, i.e. $1 \times 10^{9} \mathrm{CFU} / \mathrm{ml}$. Meantime, with the same concentration, the percentages of rot reduction were ranged between $78.9 \%$ for isolate $\mathrm{Mg} 181$ and $60.2 \%$ for Isolate $\mathrm{Mg} 57$.

However, at $5 \times 10^{8} \mathrm{CFU} / \mathrm{ml}$, the percentages of rot reduction was $100 \%$ for the isolates $\mathrm{Mg} 39$ and $\mathrm{Mg} 147$ and was ranged between $69.5 \%$ for isolate Mg 111 and 38.3 for Isolate Mg 156. The percentage of rot at the lowest tested dose of washed cells of yeast isolates, i.e. $6.6 \times 10^{7} \mathrm{CFU} / \mathrm{ml}$, showed higher values as compared with control (check). It ranged from $16.5 \%$ to $96.6 \%$ for the nine isolates under study. Three isolates i.e. Mg 111, Mg 156 and $\mathrm{Mg} 165$ had not significant reduction of rot as compared with control at lowest tested dose of washed yeast cells.

In general, the efficacy of the yeast isolates for controlling lesions development depended on the cell concentration $(\mathrm{CFU} / \mathrm{ml})$ of the yeast isolate under test as efficacy decreased by decreasing the concentration. However, the results demonstrate that the isolates $\mathrm{Mg} 147$ and $\mathrm{Mg} 39$ had high potential to control Lasiodiplodia rot on mango fruits and reduced infected area more than $90 \%$ as compared with control when used at $1 \times 10^{8} \mathrm{CFU} / \mathrm{ml}$.

\section{Testing the activity of culture filtrate}

The relative abilities of different crude culture filtrates of nine yeast isolates under study to reduce germination of conidia of $L$. theobromae were assessed. All cell free culture filtrates reduced percentage of spore germination of $L$. theobromae after mixed and incubated at $24 \pm 1^{\circ} \mathrm{C}$ in moist chamber for 21 h. Data in Figure (1) indicated that cell free culture filtrates of yeast isolates divided into three groups. The First group included isolates Mg21, Mg57, Mg156 and Mg165 which inhibited percentage of spore germination by more than $75 \%$. The second group contained isolates $\mathrm{Mg} 10$, Mg111, Mg147 and Mg181 which reduced percentage of spore germination ranged between $66.8-54.7 \%$. The third group enclosed isolate Mg39 which did not prevent more than $38 \%$ of spore germination.

On the other hand, Lasiodiplodia Lesion Area $\left(\mathrm{mm}^{2}\right)$ and Percentage of infected area as compared with control (PIACC) were recorded after Zebda mango fruit were treated by cell free culture filtrates of nine yeast isolates and challenged with $L$. theobromae spore suspension $\left(1 \times 10^{5}\right.$ conid$\mathrm{ia} / \mathrm{ml}$ ). Data in Table (3) Show that all cell free cul- ture filtrates of the nine yeast isolates reduced Lasiodiplodia lesion area and percentage of rot as compared with control (PIACC). The percentages of rot reduction were ranged between $89.8 \%$ for isolate $\mathrm{Mg} 156$ and $41.7 \%$ for Isolate Mg 39. However, there were no significant differences among isolates $\mathrm{Mg}$ 156, Mg 21 and $\mathrm{Mg} 57$.

\section{1-Methylcyclopropene (1-MCP) application}

Smart Fresh was used to release 1-MCP, following the manufacturer's recommendations. 1MCP treatment significantly reduced the infected area $\mathrm{mm}^{2}$ on mango fruit inoculated with $L$. theobromae during the fourteen days of storage (Table 4). Compared to the control, 1-MCP treatment reduced infected area $\mathrm{mm}^{2}$ by $18.7 \%$ during storage at $16 \pm 1^{\circ} \mathrm{C}$ for 14 days. However, 1 -MCP treatment significantly improved efficacy of isolates Mg147 and Mg39. No lesion developed on the fruit treated with the isolate $\mathrm{Mg} 147$ at all tested concentrations with exception of the lowest concentration i.e. $6.6 \times 10^{7} \mathrm{CFU} / \mathrm{ml}$ which exhibited $87.3 \%$ of rot reduction. Meantime, with the same concentration, no lesion developed on the fruit treated with the isolate $\mathrm{Mg} 39$ at the three higher tested concentrations. Meanwhile, the percentages of rot reduction ranged between $94.1 \%-81.3 \%$ for $1 \times 10^{8}$ and $6.6 \times 10^{7} \mathrm{CFU} / \mathrm{ml}$ respectively.

\section{Identification of promising yeast isolates}

According to screening results, the yeast isolates Mg147 and Mg39 were the most effective bioagents to control of lasiodiplodia rot of mango fruits in this study. After the analysis of data from the YT plates with the MLCLUST programme, yeast isolate $\mathrm{Mg} 147$ was identified to be Candida multisgemmis. The probability and similarity were 100 and 0.51 respectively. However, yeast isolate Mg39 was identified as Pichia guilliermondii A and the probability and similarity were 97 and 0.66 respectively.

\section{DISCUSSION}

Yeasts are particularly interesting microorganisms in a biological control of postharvest diseases. They are relatively easy to produce and maintain and have several characteristics that can be manipulated in order to improve its use and efficiency. Distribution of yeasts in nature is partially determined by nutritional characteristics of substrate, biogeographical characteristics and dispersal agents (Lachance et al 2003). Yeasts do not 
Figure.1 Percent of Lasiodiplodia theobromae spore ${ }^{(1)}$ germination after mixed $^{(2)}$ with cell free yeast culture filtrate of different isolates and incubated at $24 \pm 1^{\circ} \mathrm{C}$ in moist chamber for $21 \mathrm{~h}$.

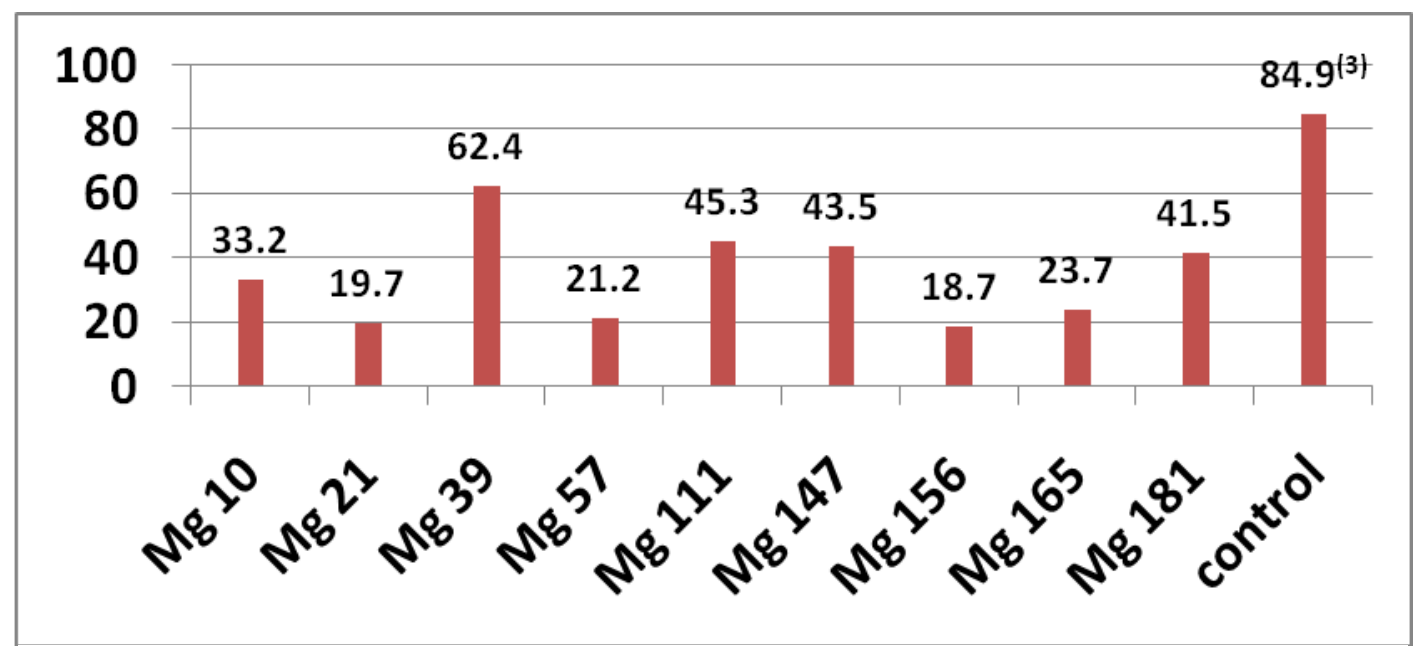

(1) L. theobromae spore suspension $\left(1 \times 10^{5}\right.$ conidia $\left./ \mathrm{ml}\right)$.

(2) A $1 \mathrm{ml}$ of spore suspension was mixed with $2 \mathrm{ml}$ of a sterilized cell free yeast culture filtrate.

(3) Two $\mathrm{ml}$ of sterile fresh NYDB medium was added instead of cell free yeast cultural filtrate for used as control (check treatment).

Table 3. Infected area $\mathrm{mm}^{2}$ and percentage of infected area as compared with control (PIACC) $^{(1)}$ of wounded Zebda mango fruit, treated with $25 \mu \mathrm{l}$ of the supernatant of different yeast isolates, and inoculated with $25 \mu \mathrm{l}$ of $L$. theobromae $\left(1 \times 10^{5}\right.$ conidia/ $\left.\mathrm{ml}\right)$, then stored for 6 days at $23 \pm 1^{\circ} \mathrm{C}$

\begin{tabular}{|c|c|c|c|c|c|}
\hline Isolates & Area $\mathrm{mm}^{2}$ & PIACC & Isolates & Area $\mathrm{mm}^{2}$ & PIACC \\
\hline $\operatorname{Mg} 10$ & $354.5 \mathrm{e}$ & 19.8 & Mg 147 & 829.2 c & 46.2 \\
\hline $\operatorname{Mg} 21$ & $220.2 \mathbf{f}$ & 12.3 & $\operatorname{Mg} 156$ & $182.6 \mathbf{f}$ & 10.2 \\
\hline Mg 39 & 1045.8 b & 58.3 & Mg 165 & $426.2 \mathrm{e}$ & 23.8 \\
\hline Mg 57 & $247.3 \mathbf{f}$ & 13.8 & Mg 181 & 593.7 d & 33.1 \\
\hline $\operatorname{Mg} 111$ & $671.6 \mathrm{~d}$ & 37.4 & Contro|(2) & $1793.6 \mathbf{a}$ & 100 \\
\hline
\end{tabular}

(1) PIACC $=$ Infected area $\left(\mathrm{mm}^{2}\right)$ for treatment/ Infected area $\left(\mathrm{mm}^{2}\right)$ for control $\times 100$.

(2) Wounds treated with sterile fresh NYDB and pathogen spore suspension were used as control (check).

(3) Means followed by the same letter are not significantly different according to Duncan's multiple range test $(p=0.05)$.

occur randomly throughout the biosphere, and each yeast community may be defined by its habitat (Lachance and Starmer, 1998). Therefore, the present work proposed that the appropriate site to search for a yeast biocontrol agents against mango fruit rots is the surface of mango fruits. Thus, we isolated a collection of yeasts, which associated healthy mango fruits in different geographical locations in Egypt i.e. Giza, Cairo, Qalyubia, Faiyum, Beni Suef, Al-Sharqia and Gharbia. Isolation of locally yeast antagonists is more desirable be- cause the antagonists isolated in specific geographic areas may be more effective against the pathogen strains present in that locale (Vero et al 2002 and Bouzerda et al 2003). Moreover, The presence of yeast strains on mango fruits reflects their abilities to tolerate the hostile conditions present on the surface of fruits, namely: low nutrient availability, UV radiation, rapid climatic changes (Leibinger et al 1997) consequently, reflects their ability to colonize and survive on the target host tissue i.e. mango fruits. The evaluation 
Table 4. Infected area $\mathrm{mm}^{2}$ and percentage of infected area as compared with control ${\text { (PIACC })^{(1)} \text { of mango fruit }}^{(2)}$, exposed to $1-\mathrm{MCP}^{(3)}$, wounded and treated ${ }^{(4)}$ with different concentrations of yeast cells of two isolates, and inoculated with Lasiodiplodia theobromae, then stored at $16 \pm 1^{\circ} \mathrm{C}$ for 14 days.

\begin{tabular}{|c|c|c|c|c|}
\hline Isolates (5) & \multicolumn{2}{|c|}{ Mg39 } & \multicolumn{2}{|c|}{ Mg147 } \\
\hline Concentration (CFU/ml) & Area $\mathrm{mm}^{2}$ & PIACC & Area $\mathrm{mm}^{2}$ & PIACC \\
\hline $1 \times 10^{9}$ & $0.0 \mathrm{f}$ & 0.0 & $0.0 \mathrm{f}$ & 0.0 \\
\hline $5 \times 10^{8}$ & $0.0 \mathrm{f}$ & 0.0 & $0.0 \mathrm{f}$ & 0.0 \\
\hline $2 \times 10^{8}$ & $0.0 \mathrm{f}$ & 0.0 & $0.0 \mathrm{f}$ & 0.0 \\
\hline $1 \times 10^{8}$ & 97.9 e & 5.9 & $0.0 \mathrm{f}$ & 0.0 \\
\hline $6.6 \times 10^{7}$ & $308.8 \mathrm{c}$ & 18.7 & 209.4 d & 12.7 \\
\hline Control $^{(6)}$ with 1-MCP & $1346.5 b$ & 81.3 & $1346.5 b$ & 81.3 \\
\hline Control $^{(6)}$ without1 - MCP & $1655.0 \mathbf{a}$ & 100 & $1655.0 \mathbf{a}$ & 100 \\
\hline
\end{tabular}

(1) PIACC = Infected area $\left(\mathrm{mm}^{2}\right)$ for treatment/ Infected area $\left(\mathrm{mm}^{2}\right)$ for control $\times 100$.

(2) Mango fruit cv. Ewais treated at mature green stage.

(3) SmartFresh (0.14\% 1-MCP) was used to release 1-MCP (625 $\mathrm{nL} \mathrm{L}^{-1}, 1 \mathrm{~g}$ per $\mathrm{m}^{3}$ chamber).

(4) Mango fruit inoculated by $25 \mu \mathrm{l}$ of different concentrations of washed cells of yeast tested isolates and

60-90 minutes later challenged with $25 \mu \mathrm{l} 1 \times 10^{5}$ conidia/ml of $L$. theobromae.

(5) Yeast isolates sources were mango fruits that did not exposed to chemical sprays for several weeks prior to picking

(6) Wounds treated with sterile distilled water and pathogen spore suspension were used as control (check).

(7) Means followed by the same letter are not significantly different according to Duncan's multiple range test $(p=0.05)$.

of epiphytic yeasts that naturally occurring on fruit surfaces as potential antagonists against postharvest fungal pathogens of many commodities have been reported (Chalutz and Wilson, 1990; Chand-Goyal and Spotts, 1997; Lima et al 1998; Ippolito et al 2000; Shehata et al 2006 and Abraham et al 2010; Janisiewicz et al 2010 and Oro et al 2014). The obtained results showed that an increase in the yeast cell concentration from $10^{7}$ to $10^{9} \mathrm{CFU} / \mathrm{ml}$ provided more effective control of Lasiodiplodia fruit rot of mango. In this respect, Droby et al (1989) reported that an increase of Debaryomyces hansenii concentration resulted in more effective biocontrol of Penicillium digitatum. El-Ghaouth et al (2002) indicated that microbial antagonists are more effective in controlling postharvest decay when applied at $10^{8} \mathrm{CFU} / \mathrm{ml}$; and often no control of decay was observed when antagonistic yeasts were applied at $10^{5} \mathrm{CFU} / \mathrm{ml}$. Lahlali et al $(2004,2005)$ found that an increase of antagonist concentration resulted in greater effectiveness against post-harvest fungal pathogens at low pathogen pressure.

In the present research, two yeast antagonists were identified as Pichia guilliermondii A for the isolate $\mathrm{Mg} 39$ and Candida multisgemmis for the

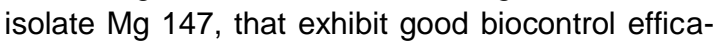

cy against Lasiodiplodia fruit rot of mango caused by $L$. theobromae for 14 days at $16 \pm 1^{\circ} \mathrm{C}$. This suggests that the ability of the selected yeast antagonists to grow and survive under mild cold storage temperatures, a necessary feature for a postharvest biocontrol agent (Wisniewski and Wilson 1992). From the results of testing the activity of culture filtrate, it was assumed that antibiosis is not important aspect of their mode of action especially for the isolate $\mathrm{Mg}$ 39. Other possible modes of action are: a) Competition for space and nutrients, (Filonow, 1998; Spadaro et al 2002). Zhang et al (2011) showed that competition for sugars and nitrates plays a key role in the interactions of $P$. guilliermondii strain M8 against Botrytis cinerea on apples. b) Direct interaction with the pathogen (direct parasitism), Wisniewski et al (1991) and Zhang et al (2011) revealed that the yeast $P$. guilliermondii strongly adhered to the hyphae and spores of $B$. cinerea. Moreover, $P$. guilliermondii shows a high activity of $\beta-1,3$ - glucanase enzyme and chitinases in minimal salt media with different carbon sources that could result in the degradation of the fungal cell walls (Jijakli \& Lepoivre, 1998 and Zhang et al 2011).; c) Induction of host defence mechanisms, the antagonist may induce wound healing processes and defence reaction of 
the host tissue. Application of Pichia guilliermondii, Debaryomyces hansenii or Candida oleophila to citrus peel wounds induced production of ethylene, increase of phenylalanine ammonia lyase (PAL) activity and accumulation of the phytoalexins scoparone, scopoletin in citrus peel strips. It provides evidence of the enhanced production of secondary metabolites that are needed to inhibit pathogen infection (Droby and Chalutz 1994; Arras and Arru 1999; Droby et al 2002).

Concerning the safety of using yeasts as biocontrol agents, the identified yeasts here are taxonomically distinct from the human pathogens. In this respect, toxicological studies of Arras et al 1999 indicated that no animals (either controls (check) or inoculated subjects) showed signs of illness distress or abnormal behaviour. Anatomopathological and histological examinations of the liver, kidneys, lungs and spleen of inoculated subjects did not reveal a picture significantly different from the controls (check). The results of pathogenicity tests excluded any possibility of the yeast $P$. guilliermondii being toxic to guinea pigs and mice. Meanwhile, Candida multigemmis (Buhagiar) S.A. Mey. \& Yarrow Synonymy: Torulopsis multisgemmis Buhagiar = Torulopsis multigemmis Buhagiar =Candida multis-gemmis (Buhagiar) S.A. Mey. \& Yarrow, was isolated from raspberries and described by Buhagiar (1975). He found that growth of all strains was abundant at $20^{\circ} \mathrm{C}$, sparse at $30^{\circ} \mathrm{C}$, and absent at $37^{\circ} \mathrm{C}$ on $\mathrm{YM}$ agar after 3 days, hence this isolate has no potentially to cause hazards to human.

On the other hand, we observed that 1-MCP treatment significantly reduced the infected area $\mathrm{mm}^{2}$ on mango fruit inoculated with $L$. theobromae and significantly improved efficacy of isolates Mg147 (Candida multisgemmis) and Mg39 (Pichia guilliermondii A) in controlling Lasiodiplodia rot. It is a general view that disease resistance of fruit is closely related to the degree of ripeness. As ripening of mango fruit was significantly inhibited by 1 MCP, the disease resistance would be expected to be enhanced by 1-MCP. However, the effect of 1MCP on various diseases has been inconsistent with results being species specific. In some cases 1-MCP treatment increased disease susceptibility while in other cases 1-MCP treatment decreased diseases Watkins (2006). Saftner et al (2003) found that 1-MCP with or without pre-storage heat treatment reduced decay of apple due to wound inoculation by $P$. expansum, Botrytis cinerea, Colletotrichum acutatum at the time of harvest and after CA storage, probably by maintaining firmness and thereby resistance to infection. Decay incidence of peaches after inoculation with $P$. expansum was slightly reduced by 1-MCP treatment, and it was suggested that resistance in these fruit was related to higher activities of phenylalanine ammonialyase, polyphenoloxidase and peroxidase in the inoculated fruit treated by 1-MCP (Liu et al 2005). Reduced decay caused by brown rot, Monilinia laxa, was found in 1-MCP-treated plums (Menniti et al 2004). 1-MCP treatment significantly reduced decay incidence of loquat fruit. Meanwhile, 1-MCP treatment induced higher activities of two defencerelated enzymes-chitinase and $\beta$-1,3-glucanaseduring 6 days storage (Cao and Zheng 2010). Treating apples with 1-MCP usually decreased the percentage of rotten fruits both directly after storage and after the shelf life period (Jeziorek et al 2010). Sivakumar et al (2012) found that combined effect of 1-MCP (500 nL L-1) and controlled atmosphere cold storage conditions showed less anthracnose incidence $(30 \%)$ than the untreated control mango fruit (65\%) after the shelf life at $25^{\circ} \mathrm{C}$ for $14-16$ days.

In conclusion, this research allowed constituting a collection of two yeast isolates that have potential in biological control as well as compatible with 1-MCP for controlling postharvest Lasiodiplodia rot. Other work are needed either in the directions of mode of action and human health especially for Isolate Mg 147 (Candida multisgemmis) or in compatibility with other postharvest control practice to enhance its antagonistic effects as well as studying the effectiveness against a wide range of postharvest pathogens.

\section{REFERENCES}

Abano, E.E. and Sam-Amoah, L.K. 2012. Application of antagonistic microorganisms for the control of postharvest decays in fruits and vegetables. International Journal of Advanced Biological Research (I.J.A.B.R.) 2: 1-8.

Abraham, A.O., Laing, M.D. and Bower, J.P. 2010. Isolation and in vivo screening of yeast and Bacillus antagonists for the control of Penicillium digitatum of citrus fruit. Biological Control 53: 32-38.

Anonymous 2013. Bulletin of the Agriculture Statistics, Part (2) Summer \& Nili Crops, 2011/2012. Ministry of Agriculture and Land Reclamation, Economic Affairs Sector, Egypt.

Arras, G. and Arru, S. 1999. Integrated control of postharvest citrus decay and induction of phytoalexins by Debaryomyces hansenii. Advances in Horticultural Science 13: 76-81. 
Arras, G., Nicolussi, P. and Ligios, C. 1999. Non-toxicity of some antifungal yeasts (Pichia guilliermondii, Rhodotorula glutinis and Candida oleophila) in laboratory animals. Annali di Microbiologia ed Enzimologia, 49: 125-131.

Blankenship, S.M. and Dole, J.M. 2003. 1Methylcyclopropene: a review. Postharvest. Biol. Technol. 28: 1-25.

Bouzerda, L., Boubaker, H., Boudyach, E.H., Akhayat, O. and Aoumar, A.A.B. 2003. Selection of antagonistic yeasts to green mold disease of citrus in Morocco. Journal of Food, Agriculture and Environment 1: 215-218.

Buhagiar, R.W.M. 1975. Torulopsis bacarum, Torulopsis pustula and Torulopsis multisgemmis sp. nov., Three New Yeasts from Soft Fruit. Journal of General Microbiology 86: 111.

Cao, S. and Zheng, Y. 2010. Effect of 1methylcyclopropene on anthracnose rot caused by Colletotrichum acutatum and disease resistance in loquat fruit. J. Sci. Food Agric. 90:2289-2294.

Chalutz, E. and Wilson, C.L. 1990. Postharvest biocontrol of green and blue mold and sour rot of citrus fruit by Debaryomyces hansenii. Plant Dis. 74: 134 -137.

Chand-Goyal, T. and Spotts, R.A. 1997. Biological control of postharvest diseases of apple and pear under semi commercial and commercial conditions using three saprophytic yeasts. Biol. Control 10: 199-206.

Conway, W.S. 1982. Effect of postharvest calcium treatment on decay of Delicious apples. Plant Dis. 66:402-403.

Droby, S., and Chalutz, E. 1994. Mode of action of biocontrol agents for postharvest diseases. In: Biological Control of Postharvest Diseases of Fruits and Vegetables-Theory and Practice. Wilson, C.L. and M.E. Wisniewski, (eds). CRC Press, Boca Raton, FL. pp. 63-75.

Droby, S., Chalutz, E., Wilson, C.L. and Wisniewski, M. 1989. Characterization of the biocontrol activity of Debaryomyces hansenii in the control of Penicillium digitatum on grapefruit. Can. J. Microbiol. 35: 794-800.

Droby, S., Vinokur, V., Weiss, B., Cohen, L., Daus, A., Goldschmidt, E.E. and Porat, R. 2002. Induction of resistance to Penicillium digitatum in grapefruit by the yeast biocontrol agent Candida oleophila. Phytopathology 92: 393-399.

El-Ghaouth, A., Wilson, C.L., Wisniewski, M.E., Droby, S., Smilanick, J.L. and Korsten, L.
2002. Biological control of postharvest diseases of citrus fruits. pp. 288-312. In: Gnanamanickam, S.S. (ed.). Biological Control of Crop Diseases. Marcel Dekker, New York, USA.

Faasema, J., Alakali, J.S. and Abu, J.O. 2014. Effects of Storage Temperature on 1Methylcyclopropene-Treated Mango (Mangnifera Indica) Fruit Varieties. Journal of Food Processing and Preservation 38: 289-295.

Falik, E.S., Grinberg, S., Gambourg, M. and Lurie, S. 1995. Prestorage heat treatment reduces pathogenicity of Penicillium expansum in apple fruit. Plant Pathol. 45: 92-97.

Filonow, A.B. 1998. Role of competition for sugars by yeasts in the biocontrol of grey mould of apple. Biocontrol Sci. Technol. 8: 243-256.

Gullino, M.L. and Kuijpers, L.A.M. 1994. Social and Political Implications of Managing Plant Diseases with Restricted Fungicides in Europe. Annu. Rev. Phytopathol. 32: 559-579.

Haggag, Wafaa, M. 2010. Mango diseases in Egypt. Agric. Biol. J.N. Am. 1: 285-289.

Hu, M.J., Gao, Z.Y., Zhang, Z.K., Yang, F.Z. and Li, M. 2013. Resistance of Botryodiplodia theobromae to carbendazim and the fungicides screening for mango stem end rot control. Acta Hort. (ISHS) 992: 407-414.

Ippolito, A., El-Ghaouth, A., Wisniewski, M. and Wilson, C. 2000. Control of postharvest decay of apple fruit by Aureobasidium pullulans and induction of defense responses. Postharv. Biol. 19: 265-272.

Janisiewicz, W.J. 1987. Postharvest biological control of blue mold on apples. Phytopathology 77: 481-485.

Janisiewicz, W.J. 1991. Control of postharvest diseases of fruits with biocontrol agents. Technical Bulletin No. 125, 13 p., Food and Fertilizer Technology Center, Taipei, Taiwan.

Janisiewicz, W.J., Kurtzman, C.P. and Buyer, J.S. 2010. Yeasts associated with nectarines and their potential for biological control of brown rot. Yeast 27: 389-398.

Jeziorek, K., Woźniak, M. and Tomala, K. 2010. Response of 'golden delicious' apples to postharvest application of 1-methylcyclopropene (1$\mathrm{mcp}$ ) in conditions of normal and controlled atmosphere. Journal of Fruit and Ornamental Plant Research 18: 223-237.

Jijakli, M.H. and Lepoivre, P. 1998. Characterization of an exo- $\beta-1,3-$ glucanase produced by Pichia anomala strain K, antagonist of Botrytis cinerea on apples. Phytopathology 88: 335343. 
Kobiler, I., Shalom, Y., Roth, I., Akerman, M., Vinokour, Y., Fuchs, Y. and Prusky, D. 2001. Effect of 2,4-dichlorophenoxyacetic acid on the incidence of side and stem end rots in mango fruits. Postharvest Biology and Technology 23: 23-32.

Korsten, L. 2006. Advances in control of postharvest diseases in tropical fresh produce. International Journal of Postharvest Technology and Innovation 1: 48-61.

Lachance, M.A. and Starmer, W.T. 1998. Ecology and yeasts In: The yeasts, a Taxonomic Study, 4th edition, (eds. Kurtzman, C.P. and Fell, J.W.), Elsevier, Amsterdam. pp. 21-30.

Lachance, M.A., Bowles, J.M. and Starmer, W.T. 2003. Geography and niche occupancy as determinants of yeast biodiversity: the yeast-insect-morning glory ecosystem of Kipuka Puaulu, Hawai. FEMS Yeast Res. 4: 105111.

Lahlali, R., Serrhini, M.N. and Jijakli, M.H. 2004. Efficacy assessment of Candida oleophila (strain O) and Pichia anomala (strain K) against major postharvest diseases of citrus fruits in Morocco. Communications in Agricultural and Applied Biological Sciences 69: 601609.

Lahlali, R., Serrhini, M.N. and Jijakli, M.H. 2005. Development of a biological control method against postharvest diseases of citrus fruits. Communications in Agricultural and Applied Biological Sciences 70: 47-58.

Leibinger, W., Breuker, B., Hahn, M. and Mendgen, K. 1997. Control of postharvest pathogens and colonization of apple fruit surface by antagonistic microorganisms in the field. Phytopathology 87: 1103-1110.

Lima, G., De Curtis, F., Castoria, R. and De Cicco, V. 1998. Activity of the yeasts Cryptococcus laurentii and Rhodotorula glutinis against postharvest rots on different fruits. Biocontrol Sci. Technol. 8: 257-267.

Liu, H.X., Jiang, W.B., Zhou, L.G., Wang, B.G. and Luo, Y.B. 2005. The effects of 1methylcyclopropene on peach fruit (Prunus persica L. CV. Jiubao) ripening and disease resistance. Int. J. Food Sci. Technol. 40:1-17.

Mari, M., Neri, F. and Bertolini, P. 2007. Novel Approaches to Prevent and Control Postharvest Diseases of Fruit. Stewart Postharvest Review, 3(6): 1-7.

Mattoo, A.K. and Modi, V.V. 1969. Ethylene and Ripening of Mangoes. Plant Physiol. 44: 308310.
Menniti, A.M., Gregori, R. and Donati, I. 2004. 1methylcyclopropene retards postharvest softening of plums. Postharvest Biol Technol 31:269-275.

Mitra, S. 1997. Mango. In: Mitra, S.K. and Baldwin, E.A. (eds.) Postharvest Physiology and Storage of Tropical and Subtropical Fruits. CAB International, Wallingford, UK, pp. 122-185.

Nally, M.C., Pesce, V.M., Maturano, Y.P., Toro, M.E., Combina, M., Castellanos de Figueroa, L.I. and Vazquez, F. 2013. Biocontrol of fungi isolated from sour rot infected table grapes by Saccharomyces and other yeast species. Postharvest Biology and Technology 86: 456-462.

Nunes, C.A. 2012. Biological control of postharvest diseases of fruit. Eur. J. Plant Pathol. 133: 181-196.

Oro, L., Feliziani, E., Ciani, M., Romanazzi, G. and Comitini, F. 2014. Biocontrol of postharvest brown rot of sweet cherries by Saccharomyces cerevisiae Disva 599, Metschnikowia pulcherrima Disva 267 and Wickerhamomyces anomalus Disva 2 strains. Postharvest Biology and Technology 96: 64-68.

Patino-Vera, M., Jimenez, B., Balderas, K., Ortiz, M., Allende, R., Carrillo, A. and Galindo, E. 2005. Pilot-scale production and liquid formulation of Rhodotorula minuta, a potential biocontrol agent of mango anthracnose. Journal of Applied Microbiology 99: 540550.

Plan, M.R.R., Joyce, D.C., Ogle, H.J. and Johnson, G.I. 2002. Mango stem-end rot (Botryosphaeria dothidea) disease control by partial pressure infiltration of fungicides. Australian Journal of Experimental Agriculture 42: 625-629.

Plascencia-Jatomea, M., Viniegra, G., Olaya, R., Castillo-Ortega, M.M. and Shirai, K. 2003. Effect of chitosan and temperature on spore germination of Aspergillus niger. Macromol Biosci 3: 582-586.

Prusky, D., Kobiler, I., Miyara, I. and Alkan, N. 2009. Fruit Diseases. In: Litz, R.E.(ed.) The Mango, $2^{\text {nd }}$ Edition: Botany, Production and Uses. CAB International, Wallingford, UK, pp. 210-230.

Punithalingam, E. 1976. Botryodiplodia theobromae. CMI descriptions of pathogenic fungi and bacteria. No. 519. Kew, Surrey, England: Commonwealth Mycological Institute. 
Punithalingam, E. 1980. Plant diseases attributed to Botryodiplodia theobromae Pat. Band 71 of Bibliotheca Mycologica, Vadus, Germany: J. Cramer, $121 \mathrm{p}$.

Pusey, P.L. and Wilson, C.L. 1984. Postharvest biological control of stone fruit brown rot by $\mathrm{Ba}$ cillus subtilis. Plant Dis. 68: 753-756.

Ragsdale, N.N. and Sisler, H.D. 1994. Social and Political Implications of Managing Plant Diseases with Decreased Availability of Fungicides in the United States. Annu. Rev. Phytopathol. 32: 545-557.

Saftner, R.A., Abbott, J.A., Conway, W.S. and Barden, C.L. 2003. Effects of 1methylcyclopropene and heat treatments on ripening and postharvest decay in 'Golden Delicious' apples. J. Am. Soc. Hortic. Sci. 128: 120-127.

Sarkar, K.M., Alam, M.M., Rahman, A. and Bhuiyan, M.G. 2011. Post-harvest losses in mango value chain. Intl. J. Bio. Res. 10(5): 2531.

Sharma R.R., Singh, D. and Singh, R. 2009. Biological control of postharvest diseases of fruits and vegetables by microbial antagonists: A review. Biological Control 50: 205-221.

Shehata, S.T., Atwa, M.A. and Hegazi, M.F. 2006. Biological control of black mould rot of tomato fruits by yeasts. Annals Agric. Sci. 51: 217-233.

Silimela, M. and Korsten, L. 2006. Evaluation of pre-harvest Bacillus licheniformis sprays to control mango fruit diseases. Crop Protection 26: 1471-1481.

Silva, F. de A.S.E. and de Azevedo, C.A.V. 2009. Principal Components Analysis in the Software Assistat-Statistical Attendance. In: World Congress on Computers in Agriculture, 7, RenoNV-USA: American Society of Agricultural and Biological Engineers.

Sivakumar, D., Van Deventer, F., Terry, L.A., Polanta, G.A. and Korsten, L. 2012. Combination of 1-methylcyclopropene treatment and controlled atmosphere storage retains overall fruit quality and bioactive compounds in mango. J. Sci. Food Agric. 92: 821-830.

Smilanick, J.L., Margosan, D.A. and Henson, D.J. 1995. Evaluation of heated solutions of sulfur dioxide, ethanol, and hydrogen peroxide to control postharvest green mold of lemons. Plant Dis. 79: 742-747.

Smilanick, J.L., Margosan, D.A., Milkota, F., Usall, J. and Michael, I. 1999. Control of citrus green mold by carbonate and biocarbonate salts and influence of commercial postharvest practices on their efficacy. Plant Dis. 83:139145.

Spadaro, D., Lorè, A., Garibaldi, A. and Gullino, M.L. 2013. A new strain of Metschnikowia fructicola for postharvest control of Penicillium expansum and patulin accumulation on four cultivars of apple. Postharvest Biology and Technology 75: 1-8.

Spadaro, D., Vola, R., Piano, S. and Gullino, M.L. 2002. Mechanisms of action and efficacy of four isolates of the yeast Metschnikowia pulcherrima active against postharvest pathogens on apples. Postharvest Biol. Technol. 24: 123-134.

Spalding, D.H. 1982. Resistance of mango pathogens to fungicides used to control postharvest diseases. Plant Disease 66: 1185-1186.

Sutton, B.C. 1980. The Coelomycetes: fungi imperfecti with pycnidia, acervuli and stromata. Commonwealth Mycological Institute, Kew, Surrey, England. 696 p.

Tripathi, A., Sharma, N., Sharma, V. and Alam, A. 2013. A review on conventional and nonconventional methods to manage post harvest diseases of perishables. Researcher 5(6):619.

Vero, S., Mondino, P., Burgueno, J., Soubes, M. and Wisniewski, M. 2002. Characterization of biocontrol activity of two yeast strains from Uruguay against blue mold of apple. Postharvest Biol. Technol. 26: 91-98.

Wang, B., Wang, J., Feng, X., Lin, L., Zhao, Y. and Jiang, W. 2009. Effects of 1-MCP and exogenous ethylene on fruit ripening and antioxidants in stored mango. Plant Growth Regulation 57: 185-192.

Watkins, C.B. 2006. The use of 1methylcyclopropene (1-MCP) on fruits and vegetables. Biotechnol. Adv. 24: 389-409.

Wilson, C. and Pusey, P.L. 1985. Potential for biological control of postharvest plant diseases. Plant Dis. 69: 375-378.

Wilson, C.L., El-Ghaouth, A., Chalutz, E., Droby, S., Stevens, C., Lu, J.Y., Khan, V. and Arul, J. 1994. Potential of induced resistance to control postharvest diseases of fruits and vegetables. Plant Dis. 78: 837-844.

Wisniewski, M.E. and Wilson, C.L. 1992. Biological control of postharvest diseases of fruits and vegetables: recent advances. HortScience 27: 94-98. 
Wisniewski, M.E., Biles, C., Droby, S., Mclaughlin, R., Wilson, C.L. and Chalutz, E. 1991. Mode of action of the postharvest biocontrol yeast, Pichia guilliermondii. I. Characterization of attachment to Botrytis cinerea. Physiol. Mol. Plant Pathol. 39: 245-258.

Xu, D., Pan, R., Zheng, Z. and Wang, Z. 2004. Monitoring of the resistance of Colletotrichum gloeosporioides on mango anthracnose to the fungicide carbendazim. J.S. China Agric. Univ. doi: CNKI:SUN:HNNB.0.2004-02-009.

Zhang, D., Spadaroa, D., Garibaldi, A. and Gullino, M. 2011. Potential biocontrol activity of a strain of Pichia guilliermondii against grey mold of apples and its possible modes of action. Biological Control 57: 193-201. 